\title{
INTERNATIONAL LAW AND THE UNCERTAIN FATE OF MILITARY SUNKEN VESSELS
}

\author{
VALENTINA S. VADI*
}

\section{INTRODUCTION}

On 5 October 1804, the Spanish warship Nuestra Señora de las Mercedes had almost completed its voyage from Peru to Spain, when it was attacked by the British fleet. In the ensuing battle of Cape St. Mary almost 250 Spanish sailors died. ${ }^{1}$ Historians deem the sinking of the Mercedes to be a pivotal event in European history. Mentioning the "sad loss of the frigate Mercedes", King Carlos IV of Spain declared war against Great Britain and entered the Napoleonic wars on the side of France. ${ }^{2}$

The fateful sinking of the Mercedes and its possible recovery by a commercial salvor, ${ }^{3}$ Odyssey Marine Exploration Inc., has been the focus of a pending legal dispute. After finding the wreck, the salvor claimed ownership of it, under the law of finds ${ }^{4}$ or a salvage award under salvage law, which would entitle it to sell the recovered artefacts and receive a part of the revenues as compensation for the efforts made in finding and recovering the shipwreck. However, Spain intervened in the proceedings claiming that the Black Swan - as the salvor had code-named the shipwreck - was the Mercedes, and that, the Mercedes being a warship of the Royal Navy of Spain, it was subject to immunity from Odyssey's claims and not subject to salvage against the wishes of Spain. In parallel, Peru reclaimed the treasure, which it deemed part of its cultural patrimony, ${ }^{5}$ while the Bolivian Government expressed its interest in identifying the origin of the recovered treasure. ${ }^{6}$ Finally, twenty-five descendants of those

* Lecturer in International Law, University of Maastricht. This paper was presented at the conference Ethics, Culture and Law, New York University, Villa La Pietra, Florence, 24 April 2010. The author wishes to thank Professor Francesco Francioni for his comments on an earlier draft. The usual disclaimer applies.

${ }^{1}$ This historical account is based on Odyssey Marine Exploration, Inc. v. The Unidentified Shipwrecked Vessel, Case No. 8:07-CV-614-SDM-MAP, Magistrate's Report and Recommendation, Judge Mark Pizzo, 3 June 2009, p. 5 ff., and ibid., Case No. 8:07-CV-00614-SDM-MAP, Claimant Kingdom of Spain's Motion to Dismiss or for Summary Judgment, 22 September 2008, p. 3 ff. All the legal documents referring to this case and cited in this article may be found at: <http://www.justia.com>.

${ }^{2}$ Claimant Kingdom of Spain's Motion to Dismiss or for Summary Judgment, ibid., p. 7.

3 "Salvor" is a nautical term which indicates a person who saves a vessel or its cargo. Salvage law governs salvage, which is the act of rescuing life or property from peril in water. The goal of salvage law is thus to provide an incentive to mariners' solidarity. By way of analogy, admiralty courts have applied the concept of salvage to the recovery of ancient relics. If a private actor rescues an ancient shipwreck, thus being considered a salvor, he/she is entitled to a reward. The reward often consists of a generous percentage of the value of the saved vessel or part of the sale proceedings and auctioning of recovered artifacts. NORRIS, Benedict on Admiralty: The Law of Salvage, 1991, pp. 1-4.

${ }^{4}$ When no owner exists or can be determined, the party who recovers the property at sea is entitled to the application of the law of finds. Under this doctrine, title to the abandoned property is given to the finder. While under salvage law, the salvor merely possesses the ship, under the law of finds, he/she is entitled to property, as the law of finds assumes that "the property involved was never owned or was abandoned". See WILDER, "Application of Salvage Law and the Law of Finds to Sunken Shipwreck Discoveries", Defense Counsel Journal, 2000, pp. 92-105, p. 93.

5 "[...] The Republic of Peru affirms and restates its sovereign and other rights in property that originated in its territory or was produced by its people [...]". See Odyssey Marine Exploration, Inc. v. The Unidentified Shipwrecked Vessel, Verified Conditional Claim of the Republic of Peru, 1 August 2008, para. 5.

${ }^{6}$ See "Peru and Bolivia also Want Their Share of the Gold Found in Spanish Galleon", MercoPress South Atlantic News Agency, 29 December 2009, available at: <http://en.mercopress.com/2009/12/28/peru-andbolivia-also-want-their-share-of-the-gold-found-in-spanish-galleon>, accessed on 15 March 2010. 
aboard the Mercedes filed claims against the wreck. On 22 December 2009, the District Judge dismissed Odyssey and Peru's complaint for lack of subject matter jurisdiction and ordered Odyssey to return the artefacts to Spain. ${ }^{7}$ While the principles of international law upheld by the judge are not new, one may wonder whether customary norms of international law concerning the protection of sunken warships in the high seas are gradually crystallizing.

This study shall proceed as follows. First, it will scrutinize the Black Swan case, by focussing on the identification of the vessel and issues of jurisdiction. Second, it shall explore the international legal framework which governs the recovery of sunken warships at the international law level. Third, issues of sovereign immunity and ownership will be addressed. Finally, some conclusions are put forward.

\section{The FACTS OF THE CASE: THE IDENTIFICATION OF THE BLACK SWAN}

A fundamental issue that had to be dealt with by the judge in the Black Swan case was the identification of the vessel. Was the Black Swan the Mercedes? On the one hand, Spain needed to prove the identity of the vessel, in order to claim ownership and sovereign immunity. On the other hand, if the shipwreck was not originally a Spanish vessel, Spain would not have any claim on the wreck, if the wreck lay in international waters off the Straits of Gibraltar. As the location of the ship had not been disclosed by Odyssey, Spain suspected that the ship could be located in its territorial waters.

In early 2007, Odyssey Marine announced that it had recovered over $\$ 500$ million worth of coins from a shipwreck (or shipwrecks) at an undisclosed location. Due to alleged security reasons, Odyssey Marine refused to divulge information about the location or identity of the shipwreck (or shipwrecks), but code-named them the Black Swan. ${ }^{8}$ Instead, it brought three admiralty actions before the United States District Court for the Middle District of Florida, each relating to a different contested wreck site. ${ }^{9}$ With regard to all three wrecks, Odyssey submitted that the Court had in personam jurisdiction over the plaintiff and constructive quasi in rem jurisdiction over the defendant shipwrecked vessel. The claimant presented a possessory and ownership claim pursuant to the law of finds, or, alternately, a salvage award claim pursuant to the law of salvage, and declaratory judgment that "no government has the authority to interfere with Odyssey's exploration and/or recovery of the Defendant Shipwrecked Vessels [...]". 10

Suspecting that the coins might belong to its sunken ships, the Spanish Government moved to compel Odyssey Marine to disclose information about the locations and identities of the three wrecks and requested that all three cases be transferred to the same court. The District Court granted the motion, requiring Odyssey Marine to disclose any relevant information to Spain. Upon this disclosure, the Court determined that one of the vessels - the

${ }^{7}$ Odyssey Marine Exploration, Inc. v. The Unidentified Shipwrecked Vessel, Case No. 8:07-cv-614-T23MAP, Order of the District Judge, 22 December 2009.

${ }^{8}$ Odyssey Marine Exploration named the project Black Swan after a book by a financial analyst, Nassim Taleb. According to Taleb, the "black swan" concept refers to high-impact unexpected events.

${ }^{9}$ Odyssey Marine Exploration, Inc., v. The Unidentified Shipwrecked Vessel, Case No. 8:06-CV-16854T23-TBM, Verified Complaint in Admiralty in Rem, 13 September 2006; Odyssey Marine Exploration, Inc., $v$. The Unidentified Shipwrecked Vessel, Case No. 8:07-CV-00616-JSM-MSS, Verified Complaint in Admiralty in Rem, 9 April 2007; Odyssey Marine Exploration, Inc. v. The Unidentified Shipwrecked Vessel, Case No. 8:07cv-00614-SCB-MAP, Verified Complaint in Admiralty in Rem, 9 April 2007.

${ }^{10}$ Case No. 8:07-cv-00614-SCB-MAP, Verified Complaint in Admiralty in Rem, ibid., para. 28; Case No. 8:07-cv-00616-JSM-MSS, Verified Complaint in Admiralty in Rem, ibid., para. 29; Odyssey Marine Exploration, Inc. v. The Unidentified Shipwrecked Vessel, Case No. 8:06-cv-01685-SDM-TBM, Verified Complaint in Admiralty in Rem, 13 September 2006, para. 33. 
one located between Sardinia and Sicily in the Mediterranean Sea ${ }^{11}$ - was the SS Ancona, an Italian vessel that sank in $1915 .^{12}$ The other vessel lying "beyond the territorial waters or contiguous zone of any sovereign nation, approximately 40 miles from Land's End near the English Channel" was believed to be an English 17th century merchant ship. ${ }^{13}$ The name released to the media was the Merchant Royal. ${ }^{14}$ Therefore, as these ships were not Spanish, Spain voluntarily dismissed its claims to these wrecks. ${ }^{15}$ However, it retained interest in the third shipwreck located beyond the territorial waters or contiguous zone of any sovereign nation, approximately 100 miles west of the Straits of Gibraltar. ${ }^{16}$

According to Odyssey, the identity of the vessel could not be ascertained, because there was no shipwreck. ${ }^{17}$ When Odyssey found piles of coins on the ocean floor, it was not clear whether the relicts belonged to the Mercedes or to other vessels. The coins were found in an area known to be a historical maritime route. According to the company, no less than thirty vessels, including the Mercedes, lie in this area. The company thus contended that "there [wa]s no definitive archaeological evidence and all evidence [...] remain[ed] circumstantial". ${ }^{18}$

By contrast, according to Spain, Odyssey knew but chose not to reveal the identity of the wreck. Not only had Odyssey conducted extensive research on the history of the wreck in order to locate it, ${ }^{19}$ but - immediately after filing the complaint - Odyssey dispatched a chartered aircraft from Gibraltar resulting in 203 gold coins, 10,080 silver coins, copper ingot and military artefacts being taken from the site. ${ }^{20} \mathrm{~A}$ second aircraft chartered by Odyssey brought more than 500,000 additional coins and other artefacts to Florida. ${ }^{21}$ Spain argued that the photographs and video of the site showed the remains of the Mercedes "in precisely the condition to be expected of a wooden-hulled warship that exploded and sank two centuries

${ }^{11}$ Case No. 8:07-cv-00616-JSM-MSS, Verified Complaint in Admiralty in Rem, ibid.

12 The Ancona, an Italian-American liner, sank on 6 November 1915 in international waters south of the Sardinian coast. From a historical perspective, its recovery sheds light on a dark corner of WWI, as the Ancona, which had been making frequent trips between Naples and New York since 1908, was carrying no guns or munitions, as on board were mostly Italian emigrant when it was shelled by a German U-boat: 159 civilians perished. From a legal perspective, problems arise as to the determination of the ownership of the wreck and its artefacts. The valuable cargo, which includes 133 thousand gold coins, seems to have belonged to the Italian Government which had secretly acquired arms from the US to fight Austria. On 9 April 2007, Odyssey filed a warrant of arrest in rem establishing a "maritime lien" on the shipwreck (Case No. 8:07-cv-00616 (M.D. Fla.)). On 6 January 2010, the Tampa Tribunal did not ascertain the ownership of the vessel, but held that neither the salvagers nor the Italian Government could take any initiative without first giving 45 days' notice to the other party. See HoOPER, “Courts Curb Bounty Hunters Seeking Torpedoed Liner’s $£ 15 \mathrm{~m}$ Bullion”, The Guardian, 12 January 2010; "Nuova pagina da Tampa sul giallo dell'Ancona”, La Stampa, 18 February 2010.

${ }^{13}$ Odyssey Marine Exploration, Inc. v. the Unidentified Shipwrecked Vessel or Vessels, Case No. 8:06-cv1685-T-23MAP, Verified Complaint in Admiralty in Rem, 13 September 2006, and Odyssey Marine Exploration, Inc. v. The Unidentified Shipwrecked Vessel or Vessels, Case No. 8:06-cv-1685-T-23MAP, Report and Recommendation, 5 January 2010.

${ }^{14}$ The Merchant Royal was carrying silver, gold and jewels from Mexico to London when it sank in bad weather near the isles of Scilly in 1641. See LEONARD, "Hoard of Treasure 'Found on Wreck Off Cornwall"”, The Telegraph, 19 May 2007; "Record Wreck 'Found off Cornwall'”, BBC News, 19 May 2007, available at: <http://news.bbc.co.uk/go/pr/fr/-/2/hi/uk_news/england/cornwall/6671975.stm>.

${ }^{15}$ Odyssey Marine Exploration, Inc. v. The Unidentified Shipwrecked Vessel, Case No. 8:07-cv-616-T23MAP, Order, 4 April 2008.

${ }^{16}$ Case No. 8:07-cv-00614-SCB-MAP, Verified Complaint in Admiralty in Rem, cit. supra note 9, p. 2.

17 "No ship existed. No hull. No keel. No intact structure suggesting the presence of a vessel". See Odyssey Marine Exploration, Inc. v. The Unidentified Shipwrecked Vessel, Case No. 8:07-CV-00614-SDMMAP, Plaintiff, Odyssey Marine Exploration, Inc.'s Response to Claimant, Kingdom of Spain's Motion to Dismiss or for Summary Judgment, 17 November 2008, p. 6.
${ }^{18}$ Ibid., p. 7.
${ }^{19}$ Ibid., p. 10.
${ }^{20}$ Ibid.
${ }^{21}$ Ibid., p. 11. 
ago". ${ }^{22}$ Furthermore, the recovered coins were struck in South America, mainly in Lima, Peru. A fact consistent with the historical data that the Mercedes stopped in El Callao, the port of Lima. According to Spain, as the shipwreck is the Nuestra Señora de las Mercedes, it belongs to Spain's historical patrimony and constitutes the gravesite of Spanish servicemen. ${ }^{23}$ Furthermore, already in 2004, Spain officially notified the US Department of State that its sunken ships could not be disturbed without authorization. ${ }^{24}$ When Odyssey expressly requested Spain's consent to recover and sell artefacts from shipwrecks of historical and cultural interest to Spain, such authorization was denied. ${ }^{25}$

The Magistrate's Report concluded that the wreck was the Mercedes. ${ }^{26}$ The report found that overwhelming circumstantial evidence ${ }^{27}$ - location, coins, cannons and artefacts pointed to the Mercedes. First, the wreck lied within the likeliest zone of the Mercedes' sinking. Second, the recovered coins "dat[ed] from the latter half of the 18th century to no later than 1804; [were] all of Spanish nationality; and [were] minted almost exclusively in the 'South American Spanish Crown Colonies' and the mint in Lima in particular". ${ }^{28}$ The salvor argued that the coins could come from another vessel because Spanish coins were acceptable currency throughout the commercial world. This argument, however, was deemed to be unpersuasive. ${ }^{29}$ Third, not only did "the 17 cannons found at the site match the type the Mercedes would have carried", but the site included two culverins that historic data confirm the Mercedes was carrying when it sank. ${ }^{30}$ Fourth, according to historical records, the Mercedes carried large quantities of copper and tin ingots when it sank and "the site includes large quantities of copper and tin ingots". ${ }^{31}$ Finally, "some of the debris and artefacts show evidence of a violent explosion". ${ }^{32}$ The District Judge agreed with the Magistrate Judge, stating:

"The ineffable truth of this case is that the Mercedes is a naval vessel of Spain and that the wreck of this naval vessel, the vessel's cargo, and any human remains are the natural and legal patrimony of Spain and are entitled in good conscience and in law to lay undisturbed in perpetuity absent the consent of Spain and despite any man's aspiration to the contrary". 33

\footnotetext{
${ }^{22}$ Ibid., p. 13.
}

${ }^{23}$ Case No. 8:07-CV-00614-SDM-MAP, Claimant Kingdom of Spain's Motion to Dismiss or for Summary Judgment, cit. supra note 1, p. 3.

${ }^{24}$ Spain's notice stated that "[i]n accordance with Spanish and international law, Spain has not abandoned or relinquished its ownership or other interests with respect to [sunken vessels that were lost while in the service of the Kingdom of Spain] and/or their content [...]". The notice also stated that "salvage or other disturbance of sunken vessels or their contents in which Spain has such interests is not authorized". US DEPARTMENT OF STATE, OFFICE OF OCEAN AFFAIRS, "Protection of Sunken Warships, Military Aircraft and Other Sunken Government Property", Public Notice No. 4614, Federal Register, Vol. 69, No. 24, 5 February 2004, p. 5647 ff.. See Claimant Kingdom of Spain's Motion to Dismiss or for Summary Judgment, ibid., p. 8.

${ }^{25}$ Claimant Kingdom of Spain's Motion to Dismiss or for Summary Judgment, ibid., p. 9.

${ }^{26}$ Case No. 8:07-CV-614-SDM-MAP, Magistrate's Report and Recommendation, cit. supra note 1, p. 12.

${ }^{27}$ The applicable standard of proof did not require proof beyond any reasonable doubt but only preponderant evidence. Ibid., p. 7.

${ }^{28}$ Ibid., p. 9.

${ }^{29}$ Ibid.

${ }^{30}$ Ibid., p. 10.

${ }^{31}$ Ibid., p. 11.

${ }^{32}$ Ibid.

${ }^{33}$ Case No. 8:07-cv-614-T-23MAP, Order, 22 December 2009, cit. supra note 7, p. 4. 


\section{JURISDICTION}

After having determined the identity of the vessel, the District Judge had to ascertain his competence to settle the dispute. Admiralty courts are ordinary courts exercising jurisdiction and hearing disputes under the rules and procedures of admiralty law. In the United States, the Constitution submits maritime cases to federal courts which may sit as admiralty courts. ${ }^{34}$ However, since the wreck of the Mercedes lay in international waters and was a Spanish vessel, the question to be addressed was whether admiralty courts could exercise jurisdiction over shipwrecks belonging to sovereigns found in the high seas. As one author points out, "this appears to be an impermissible extension of prescriptive jurisdiction or even US sovereignty beyond national borders, and it is unclear why or how any third party could be bound by the courts' rulings". ${ }^{35}$ Can national courts act as "surrogates for dormant transnational authority" ? ${ }^{36}$ Can national courts fill adjudicative gaps at the international level?

The Magistrate's Report, fully endorsed by the subsequent Order of the District Judge, ${ }^{37}$ recommended that all the claims against the shipwreck be denied, and Odyssey be directed to return the recovered artifacts to Spain. The Magistrate Judge and the District Judge upheld Spain's argument that the Court was without subject matter jurisdiction under the Foreign Sovereign Immunities Act (FSIA). ${ }^{38}$ According to the FSIA and consistent case law, "a foreign state, or its property, is presumptively immune from the jurisdiction of the United States courts; unless a specified exception applies, a federal court lacks subject matter jurisdiction". ${ }^{39}$ As the Mercedes belonged to Spain, the Magistrate argued, it was immune from suit, unless Odyssey showed that an exception applied. ${ }^{40}$ In this sense, Odyssey claimed that not all the cargo aboard the Mercedes was sovereign property, and that, accordingly, the Court should split the cargo from the vessel and then, to vindicate the individual claimants, split the cargo into separate private lots. The Magistrate, however, held that such an approach would have departed from traditional admiralty practice which deems a vessel and its cargo to be inextricably intertwined. ${ }^{41}$ Furthermore, Spain's sovereign vessels are covered by the 1902 Treaty of Friendship and General Relations between the United Nations and Spain, which states that "[i]n cases of shipwreck [...] each party shall afford to the vessels of the other, whether belonging to the State or to individuals, the same assistance and protection and the same immunities which would have been granted to its own vessels in similar cases". ${ }^{42}$ In order to critically assess the Magistrate's Report and the subsequent order of the District Judge, the following section will contextualize them exploring the legal framework which governs sunken military vessels at the international law level.

${ }^{34}$ United States Constitution, Article 3, Section 2: "The judicial power [of the United States] shall extend [...] to all cases of admiralty and maritime jurisdiction [...]". As an author explains, "the Founding Fathers were interested in having a uniform federal judiciary system for maritime cases in order to enhance maritime trade and commerce". BRADLEY, "The Supreme Court and Maritime Jurisdiction", Tulane Maritime Law Journal, 20002001, p. 207 ff., p. 207.

${ }^{35}$ WRIGHT, "Keepers, Weepers, or No Finders at All: The Effect of International Trends on the Exercise of U.S. Jurisdiction and Substantive Law in the Salvage of Historic Wrecks", Tulane Maritime Law Journal, 2008-2009, p. 297 ff.

${ }^{36}$ NAFZIGER, "The Evolving Role of Admiralty Courts in Litigation Related to Historic Wreck", Harvard International Law Journal, 2003, p. $251 \mathrm{ff}$.

${ }^{37}$ Case No. 8:07-cv-614-T-23MAP, Order, 22 December 2009, cit. supra note 7.

3828 USC $\$ 1602$ ff.

${ }^{39}$ Saudi Arabia v. Nelson, 507 US 349, 355 (1993); 28 USC paras. 1604 and 1609, cited in Case No. 8:07-CV-614-SDM-MAP, Magistrate's Report and Recommendation, cit. supra note 1, p. 16.

${ }^{40}$ Ibid., p. 16.

${ }^{41}$ Ibid., p. 23. See Sunken Military Craft Act (Publ. L. No. 108-375, para. 1406 ff., 118 Stat. 2094 (28 October 2004)) para. 1408(1).

${ }^{42}$ Treaty of Friendship and General Relations, US-Spain, Article X, 3 July 1902, 33 Stat. 2105. 


\section{The Special Status of SunKen Military Vessels in InTERnational LaW}

In cases involving military vessels, strong political and diplomatic motives discourage the application of the law of finds and salvage law. ${ }^{43}$ In addition to deserving treatment as gravesites, sunken military vessels may contain objects of national security or of archaeological or historical nature. They may also contain dangerous artifacts that could pose danger to human health and the maritime environment. At the international level, a regime complex regulates public vessels. This patchwork of norms seems to coalesce and create a special status for sunken public vessels. While various provisions partially overlap, they pursue different objectives. This section attempts to scrutinize and critically assess the existing legal framework.

Military vessels and public vessels are regulated by the law of the sea. The Geneva Convention on the High Seas (CHS) provides that "[w]arships on the high seas have complete immunity from the jurisdiction of any State other than the flag State". ${ }^{44}$ It also provides that "Ships owned or operated by a State and used only on government non-commercial service shall, on the high seas, have complete immunity from the jurisdiction of any State other than the flag State". ${ }^{45}$ Although "the importance of the Geneva Convention [on the High Seas] is currently mostly historical, as an expression of the "traditional law of the sea", 46 it is worth highlighting that many of its provisions, at the time of its adoption corresponded to customary international law. As Professor Treves points out, "this seems particularly true as regards the CHS, most of which has been transported into the 1982 Convention, and whose preamble explicitly specifies that its purpose is 'to codify the rules of international law relating to the high seas". " In addition, the CHS remains binding and applicable to or between the few States that are parties to it and not parties to the United Nations Convention on the Law of the Sea (UNCLOS), ${ }^{48}$ including the United States. ${ }^{49}$ Indeed, the same provisions concerning warships and public vessels are repeated verbatim in the UNCLOS. ${ }^{50}$ Many articles of the UNCLOS are considered customary international law.

These norms are confirmed by customary norms of international law concerning State immunity, as reflected in the United Nations Convention on Jurisdictional Immunities of States and Their Property ${ }^{51}$ and the International Convention for the Unification of Certain Rules concerning the Immunity of State-Owned Vessels ${ }^{52}$ and its 1934 Additional Protocol. ${ }^{53}$

${ }^{43}$ If one adopts a systematic interpretation scrutinizing other international law instruments, it appears that the International Convention on Salvage (28 April 1989, 1953 UNTS 194) does not apply to warships and noncommercial State-owned vessels. See Article 5.

4429 April 1958, 450 UNTS 82. See Article 8.

45 Article 9.

46 Treves, "1958 Geneva Conventions on the Law of the Sea", available at: $<$ http://untreaty.un.org/cod/avl/ha/gclos/gclos.html> accessed on 23 March 2010, p. 3.

${ }^{47}$ Ibid., p. 4.

481833 UNTS 397, opened for signature 10 December 1982, entered into force 16 November 1994; as of 22 March 2010, 157 States have ratified UNCLOS. In case of conflict between the provisions of the CHS and the UNCLOS, Article 311 UNCLOS states that the UNCLOS "shall prevail, as between State parties over the Geneva Conventions on the Law of the Sea of 29 April 1958".

49 The United States signed the UNCLOS, but has not yet ratified it.

${ }^{50}$ See Articles 95 and 96.

${ }^{51}$ Although the Convention has not yet entered into force, it is deemed to reflect customary law. The Convention favors the restrictive view of sovereign immunity. Accordingly, States are not immune in respect of a commercial transaction (Article 10). Article 21 of the Convention sets forth categories of property that shall be considered as property intended for government, non-commercial purposes by the State. These categories include, inter alia, military property and property forming part of the cultural heritage or scientific interest of the 
With regard to sunken military vessels, the question is whether these norms remain applicable. On the one hand, if one interprets these legal conventions literally, there is no provision neither in the CHS nor in the UNCLOS dealing with sunken public vessels. It has been argued that "'a ship is born when she is launched, and lives so long as her identity is preserved'. Therefore, when a ship sinks and her identity is lost to the ravages of the sea, she is no longer a vessel". ${ }^{54}$ During the travaux préparatoires of the third conference on the law of the sea, the Soviet Union and other socialist countries proposed to recognize absolute sovereign immunity to sunken military vessels, alleging the existence of a customary norm of international law on the matter. ${ }^{55}$ However the proposal was not accepted.

On the other hand, the very concept of property is not limited in time, but tends to perpetuity. Maritime powers have expressed their concerns relating to sunken warships ${ }^{56}$ For instance, in this regard, Spain stated:

"In accordance with Spanish and international law, Spain has not abandoned or otherwise relinquished its ownership or other interests with respect to [...] [sunken vessels that were lost while in the service of the Kingdom of Spain and/or were transporting property of the Kingdom of Spain] and/or its contents, except by specific action pertaining to particular vessels or property taken by Royal Decree or Act of Parliament in accordance with Spanish law" (emphasis added). ${ }^{57}$

At the governmental level, a former president of the US similarly stated:

"Pursuant to the property clause of Article IV of the Constitution, the United States retains title indefinitely to its sunken State craft unless title has been abandoned or transferred in a manner Congress authorized or directed. The United States recognizes the rule of international law that title to foreign sunken State craft may be transferred or abandoned only in accordance with the law of the foreign flag State. Further, the United States recognizes that title to a United States or foreign sunken State craft, wherever located, is not extinguished by passage of time, regardless of when such sunken State craft was lost at sea" (emphasis added). ${ }^{58}$

Other States have similarly held that "[u]nder international law of the sea all the sunken warships and government aircraft remain the property of their flag State". ${ }^{2}$

Several admiralty cases have confirmed this opinion. In Hatteras, which concerned a Civil War vessel, the United States successfully argued that it retained title over the vessel,

State. Article 16(2) expressly refers to warships. For commentary, see Fox, "In Defence of State Immunity: Why the UN Convention on State Immunity Is Important", ICLQ, 2006, pp. 399-406.

5210 April 1926, 176 LNTS 199. See Article 3.

5324 May 1934, 176 LNTS 215. See Article 1.

${ }^{54}$ WALKER, "A Contemporary Standard for Determining Title to Sunken Warships: A Tale of Two Vessels and Two Nations”, University of San Francisco Maritime Law Journal, 1999-2000, pp. 311-358, p. 350, citing Tucker v. Alexandroff, 183 US 424, 438 (1902).

${ }^{55}$ See BEURIER, "Pour un droit international de l'archéologie sous-marine", RGDIP, 1989, pp. 45-68, p. 60.

${ }^{56}$ See US DEPARTMENT OF STATE, OFFICE OF OCEAN AFFAIRS, cit. supra note 24.

57 "Many such vessels also are the resting place of military and/or civilian casualties". Communication from the Embassy of Spain, Note 128, 19 December 2002, see ibid., p. 5647.

${ }^{58}$ Clinton, "Statement on United States Policy for the Protection of Sunken Warships", Weekly Compilation of Presidential Documents 195, 22 January 2001.

${ }^{59}$ See Communication from the Government of the Russian Federation to the US State Department, 3 October 2003, in US DEPARTMENT OF STATE, OFFICE OF OCEAN AFFAIRS, cit. supra note 24. 
notwithstanding a contrary statement by the Secretary of Navy, who was deemed to have acted ultra vires. ${ }^{60}$ In the Sea Hunt case, concerning the Juno and La Galga, two Spanish warships that sank in the 18th century off the coast of Virginia, the District Court held that Spain had abandoned La Galga under a 1763 treaty ending the Seven Years War, but it had not expressly abandoned Juno. ${ }^{61}$ In 2000, the Court of Appeals of the Fourth Circuit reversed the District Court with regard to La Galga, on the grounds that in the treaty Spain did not expressly abandon its properties at sea. ${ }^{62}$ The Court of Appeals also made reference to a note of the US Department of State which declared that "the doctrine of express abandonment is consistent with the customary norm of international law that title to sunken warships may be abandoned only by express act of abandonment". ${ }^{63}$ As Spain refused salvage, stating that it had no intention to rescue the ships, Sea Hunt was not entitled to a salvage award. ${ }^{64}$ The Court also confirmed the Spanish sovereign claims to the two vessels, making reference to general principles of international comity. ${ }^{65}$ As the Court expressly stated, "the protection of the sacred sites of other nations thus assists in preventing the disturbance of our own". ${ }^{66}$ Sea Hunt petitioned for certiorari to the US Supreme Court, but certiorari was denied.

Even international agreements among maritime countries seem to be based on the title of property. For instance, in the US-France Agreement Regarding the Sunken Vessel $L a$ Belle, the US Government acknowledged France's title to the wreck and France formally asserted ownership. ${ }^{67}$ In the Memorandum of Understanding between the Government of Great Britain and Canada Pertaining to the Shipwrecks HMS Erebus and HMS Terror, ${ }^{68}$ the States made reference to the principle of sovereign immunity and/or ownership. ${ }^{69}$ In the Agreement between the Netherlands and Australia concerning Dutch Old Shipwrecks, the parties did not make reference to sovereign immunity but to State property. ${ }^{70}$ A similar

${ }^{60}$ Hatteras Inc. v. The U.S.S. Hatteras, 1984 AMC 1094, pp. 1101-1102.

${ }^{61}$ Sea Hunt, Inc. v. The Unidentified Shipwrecked Vessel or Vessels, 47 F. Supp. $2^{\text {nd }}$, pp. 688, 690-92.

${ }^{62}$ Sea Hunt, Inc. v. The Unidentified Shipwrecked Vessel or Vessels, 221 F. $3^{\text {rd }}$, p. 634 ff, p. $646\left(4^{\text {th }}\right.$ Cir. 2000).

${ }^{63}$ Ibid., para. 13.

64 "It is the right of the owner of any vessel to refuse unwanted salvage", ibid., p. 647. For a critical assessment, see BEDERMAN and SPIELMAN, "Refusing Salvage”, Loyola Maritime Law Journal, 2008, p. 31 ff.

${ }^{65}$ Sea Hunt, Inc. v. The Unidentified Shipwrecked Vessel or Vessels ibid. For a commentary, see AZNARGóMEZ, "Legal Status of Sunken Warships 'Revisited”", Spanish YBIL, Vol. IX, 2003, p. 61 ff., p. 74; WALKER, cit. supra note 54, pp. 314-320.

${ }^{66}$ Sea Hunt, Inc. v. The Unidentified Shipwrecked Vessel or Vessels, ibid.

${ }^{67}$ La Belle was an auxiliary vessel of the French Navy, under the command of the explorer René Robert Cavalier. Cavalier was in charge of establishing a colony at the mouth of the Mississippi River. In 1686 the ship sank. When the shipwreck was found by archaeologists, the US and France concluded an agreement. Agreement Regarding the Wreck of La Belle, US-France, 31 March 2003. See MURPHY, "U.S.-France Agreement Regarding the Sunken Vessel La Belle", AJIL, 2003, p. 688 ff.

68 The HMS Erebus and the HMS Terror - two English ships charged with finding the fabled North West Passage - vanished in 1845. For a historical account, see SCOVAZZI, "Les épaves de navires d'état", AFDI, 2006, pp. 400-417.

${ }^{69}$ Memorandum of Understanding between the Government of Great Britain and Canada Pertaining the Shipwrecks HMS Erebus and HMS Terror, 5-8 August 1997, reprinted in GARABELLO and SCOVAZZI (eds.), The Protection of the Underwater Cultural Heritage: Before and After the 2001 UNESCO Convention, Leiden, 2003, p. 263: "[...] Britain does not waive sovereign immunity or ownership with respect to the wrecks or their contents $[\ldots] "$.

70 The Agreement (The Hague, 6 November 1972) is reprinted in GARABELLO and ScovazZI (eds.), ibid., p. 254. The preamble of the Agreement states: "The Netherlands, by virtue of article 247 of the 1789 Constitution of the Batavian Republic, is the present legal successor of the V.O.C. [Vereenigde Oostindische Compagnie]". Under Article 1 of the Agreement, "The Netherlands as successor to the property and assets of the V.O.C, transfers all its right, title and interest in and to the wrecked vessels of the V.O.C. lying on or off the coast of Western Australia [...]". 
exchange of notes between Italy and the UK solved the dispute relating to the H.M.S. Spartan, a British vessel sunk in Anzio in 1944. ${ }^{71}$

It is debatable whether the special status of sunken military shipwrecks depends on sovereign immunity. ${ }^{72}$ In the seminal Schooner Exchange case, which concerned the claim of US citizens to a ship that had been unlawfully requisitioned by the Napoleon Army and then used as a French warship, Chief Justice Marshall of the US Supreme Court stated: "[a warship] constitutes a part of the military force of her nation; acts under the immediate and direct command of the sovereign [...] the interference [of a foreign State] cannot take place without affecting [the sovereign's] power and [...] dignity". ${ }^{73}$ The decision was that US courts had no jurisdiction over a military vessel in the service of a sovereign of another country. ${ }^{74}$ The case, however, concerned a military vessel, not a sunken one. In United States v. Steinmetz, the Third Circuit held that "warships are to be treated uniquely" and concluded that "warships and their remains are [...] clothed with sovereign immunity and therefore entitled to a presumption against abandonment of title" (emphasis added). ${ }^{75}$ At the heart of the case was the bell from the C.S.S. Alabama, a Confederate warship sunk during the American Civil War. Steinmetz, a collector of antiquities, had purchased the bell in London and tried to sell it to the US in the 1970s. Instead of buying the bell, the United States claimed title to it, contending that the Alabama and its content still belonged to the US. The Court held that the bell belonged to the United States. ${ }^{76}$ In the Black Swan case, Spain successfully argued that

"The fact that a warship has sunk has no effect on its protected status under international law. The United States, Spain, and other sea-going nations recognize the rule that the site of a sunken warship may not be disturbed without the express permission of the warship's sovereign owner". ${ }^{77}$

Although sovereign immunity claims have been accepted by courts even with regard to sunken military vessels, it is worth scrutinizing the merit of such an approach. ${ }^{78}$

Under international law, sovereign immunity indicates that States are immune from legal proceedings in another State. Sovereign immunity stems from customary international law and is based on "the perfect equality and absolute interdependence of sovereigns" ${ }^{79}$ The rule par in parem non habet imperium expresses the idea that one sovereign State does not have authority over another sovereign State. ${ }^{80}$ Judges have also recognized the political significance of sovereign immunity, as "giving full effect to sovereign immunity promotes the

${ }^{71}$ Exchange of Notes Constituting an Agreement Between the Government of the United Kingdom of Great Britain and Northern Ireland and the Government of Italy regarding the Salvage of the H.M.S. Spartan, 6 November 1952, 158 UNTS 432.

${ }^{72}$ Strati lists the number of authors which support the extension of sovereign immunity to shipwrecks. STRATI, The Protection of Underwater Cultural Heritage, The Hague, 1995, p. 235. Contra, see VIERUCCI, "Le statut juridique de navires de guerre ayant coulé dans les eaux étrangères: le cas des frégates espagnoles Juno et Galga retrouvées au large des côtes des Etats-Unis", RGDIP, 2000, pp. 707-720.

${ }^{73}$ The Schooner Exchange v. Mc Faddon, 11 US 116 (1812), AJIL, 1909, p. 227 ff.

${ }^{74}$ US citizens were nonetheless compensated for the requisition of their property by a later treaty between the United States and France. See REEVES, “A Note on Exchange v. M'Faddon”, AJIL, 1924, p. 320 ff.

${ }^{75}$ United States v. Steinmetz, 763 F. Supp. 1293, 1299, D.N.J. 1991.

${ }^{76}$ At the time of its sinking the ship was in international waters. However, the same spot later has come within French territorial waters since the inception of the UNCLOS. For commentary, see YEATES, "Clearing Up the Confusion: A Strict Standard of Abandonment for Sunken Public Vessels", University of San Francisco Maritime Law Journal, 1999-2000, p. 385 ff.

${ }_{77}^{77}$ Claimant Kingdom of Spain's Motion to Dismiss or for Summary Judgment, cit. supra note 1, p. 21.

${ }^{78}$ See below in the text.

${ }^{79}$ Republic of Philippines v. Pimentel, 128 S. Ct. 2180, 2189-90 (2008), cited in Claimant Kingdom of Spain's Motion to Dismiss or for Summary Judgment, cit. supra note 1, p. 25.

${ }^{80}$ See generally CASSESE, Diritto internazionale, Bologna, 2006, p. 95 ff. 
comity that has contributed to the development of the [sovereign] immunity doctrine" ${ }^{81}$ The principle of international comity requires every sovereign State to respect the independence and dignity of every other sovereign State and not to exercise jurisdiction over the property of any State which is destined to public use.

Some authors have criticized the extension of absolute immunity to sunken military vessels, highlighting the functional aspect of the notion of warship. ${ }^{82}$ These authors admit that military activities constitute activities jure imperii and deserve absolute immunity. They note, however, that after the sinking, the warship would lose its function as a State organ. ${ }^{83}$ As the commander and the crew constitute "des elements constitutifs du navire de guerre, leur perte entraîne un changement de la nature de l'object". ${ }^{84}$ Vierucci has articulated this critique as follows:

\begin{abstract}
"la fonction de caractère politico-militaire que le navire doit assumer en tant qu'organe d'Etat conçu principalement pour le combat est sans doute inhérente à la destination du bien. Le naufrage entraîne la perte de l'identité structurelle du navire et de son aptitude potentielle à la navigation qui représente l'élément essentiel de la destinatio ad navigandum; la destination du bien subit dès lors elle aussi, à la suite du naufrage, une modification inévitable qui empêche le déroulement des fonctions gouvernementales originairement attribuées au navire" [internal citations omitted]. ${ }^{85}$
\end{abstract}

According to Vierucci, only if the shipwreck contained documents and/or instruments of a military character should immunity be recognized. ${ }^{86}$

From a theoretical perspective, this argument holds true. The reason why sovereign immunity is recognized to warships is due to their specific function. When this specific function ceases to exist, the shipwreck is no longer a warship but a wreck. From a policy perspective, however, one may wonder whether the sinking alone may change the quality of the warship and its public nature. Besides issues of property, other policy concerns arise. First, these shipwrecks should be considered as maritime graves. Maritime war graves should be treated in the same fashion as land based war graves. Customary international humanitarian law requires States to care for and preserve war graves. ${ }^{87}$ The Second Geneva Convention ${ }^{88}$ also prohibits pillage. ${ }^{89}$ Second, political reasons and issues of reciprocity have moved States to extend the concept of immunity to sunken military vessels. This opinio juris seems supported by recent qualified practice. Third, warships may also hold an important cultural value. The public policy of protecting and preserving historical and cultural objects is a common concern of mankind.

From a cultural heritage perspective, the UNCLOS recognizes the obligation of States to protect archaeological and historical objects. ${ }^{90}$ Under UNCLOS Article 303, States have

${ }^{81}$ Republic of Philippines v. Pimentel, cit. supra note 79, p. 25.

${ }^{82}$ VIERUCCI, cit. supra note 72, p. 716; CAFLISCH, "Submarine Antiquities and the International Law of the Sea", NYIL, 1982, pp. 3-32, p. 22, note 74.

${ }^{83}$ LAUTERPACHT (ed.), Lassa Oppenheim's International Law: A Treatise, London, 1955, pp. 851-852.

${ }^{84}$ VIERUCCI, cit. supra note 72, p. 716.

${ }^{85}$ Ibid., p. 717.

${ }^{86}$ Ibid.

${ }^{87}$ See AZNAR-GÓMEZ, cit. supra note 25, p. 66, note 25.

${ }^{88}$ Convention (II) for the Amelioration of the Condition of Wounded, Sick and Shipwrecked Members of the Armed Forces at Sea, 12 August 1949, 75 UNTS 85.

${ }^{89}$ Article 18.

${ }^{90}$ For a detailed analysis of UNCLOS provisions dedicated to underwater cultural heritage, see for instance, PAPA SOKAL, "International Law for the Protection of Underwater Cultural Heritage: Can Our Past Be Salvaged?", Culture Without Context, 2005. 
the duty to protect objects of an archaeological and historical nature found at sea and shall cooperate for this purpose. ${ }^{91}$ In parallel, Article 149 states that all objects of an archaeological and historical nature found on the seabed and ocean floor beyond the limits of national jurisdiction (the so-called Area) "shall be preserved and disposed of for the benefit of mankind as a whole, particular regard being paid to the preferential rights of the State or country of origin, or the State of cultural origin, or the State of historical and archaeological origin". Not only do the two provisions not define what constitutes an archaeological and historical object, but they also fail to mention the measures to be taken to protect such objects. Also, there seems to be an intrinsic ambiguity in the regime established by the Convention. Authors have highlighted that while the incipit of Article 149 seems to give preference to an internationalist conception of underwater cultural heritage ("[archaeological objects] shall be preserved and disposed of for the benefit of mankind as a whole") the remaining part of the provision seems to adopt a nationalist view of cultural objects ("particular regard being paid to the preferential rights of the State or country of origin, or the State of cultural origin, or the State of historical and archaeological origin"). ${ }^{92}$ Thus, the Convention expressly left room for the elaboration of a more detailed protection regime by a specific international instrument. ${ }^{93}$

A more specific instrument for the international protection of underwater cultural heritage is the 2001 UNESCO Convention on the Protection of the Underwater Cultural Heritage $(\mathrm{CPUCH}) .{ }^{94}$ The elaboration of the Convention reflects the increasing awareness reached within the international community of the importance of protecting underwater cultural heritage. ${ }^{95}$ The Convention defines underwater cultural heritage as

"all traces of human existence having a cultural, historical or archaeological character which have been partially or totally under water, periodically or continuously, for at least 100 years such as [...] (b) vessels, aircraft, other vehicles or any part thereof, their cargo or other contents, together with their archaeological and natural context [...]".

While this definition seems extremely broad, it concretely restricts the notion of cultural heritage to a certain timeframe. The 100-year cut-off point has been criticized as warships from the two world wars are excluded, notwithstanding their significant historical and cultural value. ${ }^{96}$

With regard to the recovery of warships and public vessels, several provisions are of interest. First, the CPUCH has to be interpreted and applied "in the context of and in a manner consistent with international law, including the United Nations Convention on the Law of the

${ }^{91}$ Article 303(1). States can establish an archaeological zone within their contiguous zone and thus may consider the removal of any archaeological or historical object from the contiguous zone as an infringement of the Convention.

${ }^{92}$ Article 149. See CURFMAN, "Thar Be a Treasure Here: Rights to Ancient Shipwrecks in International Waters - A New Policy Regime”, Washington University Law Review, 2008, pp. 181-207, p. 200.

93 Article 303(4).

94 The Convention on the Protection of Underwater Cultural Heritage (ILM, 2002, p. 40 ff.) was adopted on 2 November 2001 at the thirty-first session of the UNESCO General Conference and entered into force on 2 January 2009.

${ }^{95}$ CARDUCCI, "Introduction to the UNESCO Convention on the Protection of the Underwater Cultural Heritage", in GRENIER, NUTLEY and COCHRAN (eds.), Underwater Cultural Heritage at Risk: Managing Natural and Human Impacts, Paris, 2006, pp. 20-22.

96 "The 1998 Draft also used this 100-year cut-off point, but had a provision that a state could unilaterally decide to include remains less than 100 years old; this has now been omitted". DROMGOOLE, "2001 UNESCO Convention on the Protection of the Underwater Cultural Heritage", International Journal of Marine and Coastal Law, 2003, pp. 59-91, p. 63. 
Sea". ${ }^{97}$ More specifically, "[...] nothing in this Convention shall be interpreted as modifying the rules of international law and State practice pertaining to sovereign immunities nor any State's rights with respect to its State vessels and aircraft". ${ }^{98}$ Second, it provides that "[n]o State Party shall undertake or authorize activities directed at State vessels and aircraft in the Area without the consent of the flag State". ${ }^{99}$ The CPUCH also prohibits any intervention on these wrecks in the exclusive economic zone and the continental shelf without the authorization of the flag State. ${ }^{100}$ By contrast, in the territorial sea, the coastal State may regulate and/or authorize interventions on military sunken vessels "in the exercise of State sovereignty and the general practice among States" (emphasis added). ${ }^{101}$ However, the coastal State "should inform the flag State party to this Convention and, if applicable, other States with a verifiable link, especially a cultural, historical or archaeological link, with respect to the discovery of such identifiable state vessels [...]" (emphasis added). ${ }^{102}$ This last provision was opposed by maritime powers, ${ }^{103}$ which favored a rule requiring the consent of the flag State even in the territorial waters of another country. For instance, the UK Foreign Office explained the UK's abstention from voting on the final text of the Convention:

"The United Kingdom considers that the current text erodes the fundamental principles of customary international law, codified in [the UNCLOS], of sovereign immunity which is retained by a State's warships and vessels and aircraft used for non commercial service until expressly abandoned by that State" (emphasis added). ${ }^{104}$

This perspective seems to be confirmed by qualified practice. ${ }^{105}$ State practice and opinio juris are the constitutive elements of customary international law. However, whether a custom in this sense exists is still debated. For instance, Bedermann stated that "there is simply no rule of customary international law - today or in the past - that requires sunken warships to be expressly or affirmatively abandoned by their original sovereign owners". ${ }^{106}$ In a subsequent article, however, Bedermann admits that the phenomenon of instant custom is a remarkable feature of the modern law of the sea, and that the extension of sovereign immunities to sunken warships may become customary international law. ${ }^{107}$ Other authors

${ }^{97}$ Article 3.
${ }^{98}$ Article 2(8).
${ }_{99}$ Article 12(7).
${ }^{100}$ Article 10(7).
${ }^{101}$ Article 7(3).
${ }^{102}$ Ibid. October 2001. The Russian Federation stated "[...] the draft limits norms of international customary law related to the inviolability of sunken warship".

${ }^{104}$ UK Explanation of Vote, Foreign and Commonwealth Office, 31 October 2001, cited by DROMGOOLE, cit. supra note 96, p. 74.

${ }^{105}$ See MOMTAZ, "La Convention sur la protection du patrimoine culturel subaquatique", in NDIAYE and Wolfrum (eds.), Law of the Sea, Environmental Law, and Settlement of Disputes. Liber Amicorum Judge Thomas A. Mensah, Leiden, 2007, p. 458 ff.; AZNAR-GóMEZ, "Treasure Hunters, Sunken State Vessels and the 2001 UNESCO Convention on the Protection of Underwater Cultural Heritage", International Journal of Marine and Coastal Law, 2010, pp. 209-236, p. 219.

${ }^{106}$ BEDERMANN, "Rethinking the Legal Status of Sunken Warships”, Ocean Development \& International Law, p. 97 ff., p. 100.

${ }^{107}$ BEDERMANN, "Congress Enacts Increased Protections for Sunken Military Craft", AJIL, 2006, pp. 649-663, p. 663. 
deem that such a customary norm of international law already exists. ${ }^{108}$ It seems that a norm of customary international law is gradually coalescing in this area.

\section{Who OWns Underwater Cultural Heritage?}

The dilemma which underlies many disputes concerning cultural goods is whether these goods should be returned to the original owners who produced them, or whether the actual possessors should be privileged simply because of possession. In many circumstances, dramatic historical events characterize the history of certain cultural objects. What should be done with the recovered artifacts? Should the finders be keepers and the losers weepers? Would this solution not be simplistic and unfair with regard to the people who perished because of dramatic circumstances? If the finders were not compensated for their efforts, who would attempt to locate and recover shipwrecks? What about the danger of dispersing the memory of these historical events?

The increasing capability to reach undersea archaeological treasures has intensified the debate on related ownership and management issues. While the scientific community and the public at large demand the preservation of cultural heritage, commercial salvors who have been particularly successful in maritime excavation have recovered costs by claiming possession rights under salvage law and selling artifacts. In the current legal framework, salvage law contemplates monetary rewards and incentives for salvaging shipwrecks. However, salvage involves dilution and irremediable loss of cultural heritage. ${ }^{109}$ According to what may be called the purist view, ${ }^{110}$ commercial salvage operators are contemporary pirates and should be excluded from working on historical wreck sites. ${ }^{111}$

Still, unless salvors can recover underwater heritage, it is unlikely that this heritage will ever be brought to light. ${ }^{112}$ Not only are most countries short of funding for such works; at the same time they face a lack of expertise, equipment and historical documents. Even industrialized countries may find it difficult to invest huge monetary resources in rescuing underwater cultural heritage. While certain shipwrecks have been found accidentally and/or have been excavated by maritime archaeologists through public funding, this is rarely the case. These different positions on the appropriate legal framework to deal with underwater cultural heritage are based on different theoretical assumptions. On the one hand, the mercantilist approach aims to reward the work of salvors. On the other hand, the purist approach is based on the conception of cultural objects as the common heritage of mankind. In dealing with the clash of these conflicting interests and philosophies, courts have struggled

${ }^{108}$ For instance, Roach and Smith refer to "a moderately well-developed body of customary international law governing the treatment of sunken warships and military aircraft (as opposed to other vessels and aircraft not entitled to sovereign immunity). [...] International law recognizes that State vessels and aircraft and their associated artifacts, whether or not sunken, are entitled to sovereign immunity". ROACH and SMITH, United States Responses to Excessive Maritime Claims, 2nd ed., The Hague, 1996), p. 473. Aznar-Gómez (cit. supra note 105 , p. 223) refers to "the general customary rule of immunity of sunken state vessels".

109 See generally, VARMER, "The Case Against the 'Salvage' of the Cultural Heritage", Journal of Maritime Law \& Commerce, 1999, p. $279 \mathrm{ff}$.

${ }^{110}$ See, for instance, GARABELLO and ScOVAZZI (eds.), cit. supra note 69.

${ }^{111}$ See STRECKER, "Pirates of the Mediterranean? The Case of the 'Black Swan' and Its Implications for the Protection of Underwater Cultural Heritage in the Mediterranean Region", in VRDOLJAK and FRANCIONI (eds.), The Illicit Traffic of Cultural Objects in the Mediterranean, EUI-AEL Working Paper, 2009/9, pp. 59-73.

112 Bоотн, "The Collision of Property Rights and Cultural Heritage; the Salvors' and Insurers' Viewpoints", in HofFMAn (ed.), Art and Cultural Heritage. Law, Policy and Practice, Cambridge, 2006, p. 293 ff., p. 299. 
to settle cultural heritage disputes. Given the international dimension of most of the disputes, underwater cultural heritage has become the last frontier of the international legal debate. ${ }^{113}$

With regard to the ownership of undersea heritage, neither UNCLOS nor the CPUCH govern property rights. Article 149 of the UNCLOS states that all objects of an archaeological and historical nature found on the seabed and ocean floor beyond the limits of national jurisdiction (the so-called Area) "shall be preserved and disposed of for the benefit of mankind as a whole [...]". Underwater cultural heritage may be considered as an "integral part of the common heritage of humanity" because of its universal importance. ${ }^{114}$ The common heritage of mankind "symbolizes the unity of mankind" and "belongs" to all peoples. However, this formulation does not establish a form of collective property rights or a "distinct international cultural heritage", ${ }^{115}$ but affirms the objective of protecting underwater cultural heritage. ${ }^{116}$

Article 149 of the UNCLOS also requires that "particular regard" be paid to "the preferential rights of the State or country of origin, or the State of cultural origin, or the State of historical and archaeological origin". As Strati clarified, this vague formulation indicates that particular attention has to be paid to the cultural linkages of a given object to the communities which originated it. ${ }^{117}$ Cultural heritage is always associated with a given civilization: ${ }^{118}$ "historically and socially, it is related to a particular human group, whether a whole nation or a minority group within it". ${ }^{119}$ However, Article 149 of the UNCLOS does not clarify which community should be preferred. Underwater cultural heritage is multicultural heritage par excellence because of its cosmopolitan character. It may be relevant to the State of origin of the ship, the State of origin of the cargo, the coastal State on whose continental shelf the wreck was found and to other third States. As Strati suggested, perhaps the best approach is to adopt a case-by-case approach. ${ }^{120}$

In the case of "difficult heritage", i.e. heritage that recalls dramatic events, ${ }^{121}$ such as looting of religious goods and other riches in time of war, genocide and so on, the case for restitution becomes compelling. ${ }^{122}$ In these specific circumstances, equity infra legem requires the interpretation of Article 149 of the UNCLOS so as to allow restitution and to right

${ }^{113}$ NAFZIGER, "The Present State of Research Carried Out by the English-speaking Section of the Centre for Studies and Research", in HAGUE ACADEMY OF InTERnATIONAL LAW, The Cultural Heritage of Mankind, 2007, p. 216.

${ }^{114} \mathrm{CPUCH}$, Preamble.

115 STRATI, "Deep Seabed Cultural Property and the Common Heritage of Mankind", ICLQ, 1991, pp. 859-894, p. 860.

116 Ibid., p. 860.

${ }^{117}$ Ibid., p. 886. Strati also proposes (p. 888) to adopt the "effective link" of nationality envisaged by the International Court of Justice in the Nottebohm case (ICJ Reports, 1955, p. 4 ff.).

${ }^{118}$ See for instance, the case of the Venus of Cyrene. The case was complex because the statue is the Roman copy of a Greek original and was found in Cyrene. When Libya became an Italian colony, Italian troops took the Venus for display in Rome. See CHECHI, "Facilitating the Restitution of Cultural Objects through Cooperation: The Case of the 2001 US-Italy Agreement and Its Relevance for Mediterranean Countries", in VRDOLJAK and FRANCIONI (eds.), The Illicit Traffic of Cultural Objects in the Mediterranean, EUI-AEL Working Paper, 2009/9, p. $149 \mathrm{ff}$.

${ }^{119}$ STRATI, cit. supra note 115 , p. 860.

${ }^{120}$ Ibid., p. 889.

121 See MaCDONALD, Difficult Heritage. Negotiating the Nazi Past in Nuremberg and Beyond, London/New York, 2009, p. 1.

${ }^{122}$ See Rosenberg v. Fischer (8 June 1948, Annuaire suisse de droit international, 1949, p.139 ff.); Menzel v. List (22 AD2d 647, 253 NYS2d 43 (1st Dept. 1964) and 267 NYS2d 804, 49 Misc.2d 300 (Sup. Ct. NY Co. 1966)); Altmann v. Austria (142 F. Supp. 2d 1187 (C.D. Cal. 2001), aff'd, 317 F. 3d 952 (9th Cir. Cal. 2002), cert. granted in part, 539 US 987 (2003)). 
historical wrongs. ${ }^{123}$ Human dignity requires that adequate consideration be paid to human remains. Religious and cultural objects stolen during operations of ethnic cleansing must be returned to the relevant cultural communities. ${ }^{124}$

In the Black Swan case, Peru contended that the cultural, historical and archaeological connection was "the crucial linkage for recognizing sovereign State interests". ${ }^{125}$ In particular, Peru argued that its right to the cargo of the Mercedes was superior to Spain's "since the property physically, culturally and historically originated in Peru", ${ }^{126}$ being "extracted from Peruvian territory by [...][the forced labour of] Peruvians". ${ }^{127}$ Peru also asked the Court to "apply general admiralty principles within the broader context of contemporary international law", ${ }^{128}$ and referred to different sets of norms based upon the law of the sea, the law of State succession, and considerations of equity and international policy concerning "condemnation of colonialism, protection of permanent sovereignty over national wealth and resources, the protection of cultural heritage and the prohibition against pillage of occupied countries". ${ }^{129}$ First, Peru claimed that the Court should apply the rule set forth in Article 149 of the UNCLOS, which grants preferential rights to the State of origin. ${ }^{130}$ As mentioned above, Article 149 UNCLOS states that "particular regard" should be paid "to the preferential rights of the State or country of origin or the State of cultural origin, or the State of historical and archaeological origin". Second, Peru claimed that "modern international law on the rights and duties of successor States would grant Peru at least an equitable proportion of the treasure", ${ }^{131}$ deeming that when a nation is divided, all successor States are entitled to equitable shares of the State property, with preference given to the historical and archaeological origin. Third, Peru argued that the Court should apply principles of equity to divide the property. ${ }^{132}$ According to Peru, not only have admiralty courts applied principles of equity, but international law itself incorporates such principles. One of these principles unjust enrichment - "advances the justice-based proposition that one party should not unfairly enrich itself at the expense of another". ${ }^{133}$

In its reply, Spain acknowledged that Peru declared its independence in 1821 and that, after the defeat of the Spanish forces in the Battle of Ayacucho, Spain surrendered its territory and its objects within that territory. However, Spain pointed out that the Capitulation of Ayacucho did not provide surrender or abandonment of Spanish warships and merchant ships. On the contrary, ships were given time "to make themselves fit and leave for the Pacific Ocean". ${ }^{134}$ Spain formally recognized Peru's independence in 1879 by ratifying a peace and

${ }^{123}$ On equity in international law, see for instance, FRANCIONI, "Equity in International Law", in Wolfrum (ed.), The Max Planck Encyclopedia of Public International Law, Oxford, 2007, online edition (available at: <http://www.mpepil.com>).

${ }^{124}$ See VRDOLJAK, International Law, Museums and the Return of Cultural Objects, Cambridge, 2006.

${ }^{125}$ Case No. 8:07-cv-614-T-23MAP, Order, 22 December 2009, cit. supra note 7, p. 3.

${ }^{126}$ The Viceroyalty of Peru covered present day Peru and Chile. See Case No. 8:07-CV-614-SDM-MAP, Magistrate's Report and Recommendation, cit. supra note 1, p. 29 (hereinafter Magistrate's Report and Recommendation)

126 Ibid.

${ }^{127}$ Odyssey Marine Exploration, Inc. v. The Unidentified Shipwrecked Vessel, Case No. 8:07-cv-614-T23MAP, The Republic of Peru's Response to the Kingdom of Spain's Motion to Dismiss or for Summary Judgment, 17 November 2008, p. 2 (hereinafter Peru's Response).

${ }^{128}$ Peru's Response, p. 17.

${ }^{129}$ Magistrate's Report and Recommendation, p. 29.

${ }^{130}$ Peru's Response, pp. 17-25.

${ }^{131}$ Ibid., pp. 26-31.

${ }^{132}$ Ibid., pp. 32-34.

${ }^{133}$ Ibid., pp. 33.

${ }^{134}$ Odyssey Marine Exploration, Inc. v. The Unidentified Shipwrecked Vessel, Kingdom of Spain Reply to Claimant Republic of Peru Response to Spain's Motion to Dismiss or for Summary Judgment, 26 January 2009, p. 4 (hereinafter Spain's Reply). 
friendship treaty which established "a solid and inviolable peace between the Republic of Peru and His Majesty the King of Spain". ${ }^{135}$

Furthermore, Spain contended that Peru has no claim under Article 149 of UNCLOS. First, Article 149 - Spain argued - was inapplicable because Spain, not Peru, was the State or country of origin: "when the Mercedes sailed from El Callao, everything placed on board there 'originated' in what was part of Spain". ${ }^{136}$ Second, Spain claimed that Article 149 concerns only objects found in the Area, that is, the seabed and ocean floor and subsoil thereof beyond the limits of national jurisdiction. Peru acknowledged that the Mercedes was not found in the Area. Therefore, Spain argued that Article 149 is inapplicable. ${ }^{137}$ Third, Spain relied on Article 95 of UNCLOS which provides for sovereign immunity of warships. Fourth, Spain highlighted that Peru has neither signed nor ratified UNCLOS. Even if Peru was a party to UNCLOS, Spain claimed that under Article 286 of UNCLOS, any dispute concerning its interpretation or application should be brought before the International Tribunal of the Law of the Sea or the International Court of Justice or a special tribunal constituted in accordance with other parts of the Convention. ${ }^{138}$ Therefore, "a US court [wa]s not the proper forum for Peru's UNCLOS-dependent theories". ${ }^{139}$

Spain also opposed Peru's claim under international State succession principles, claiming that Peru was seeking to raise a non-justiciable political question. ${ }^{140}$ First, the 1983 Vienna Convention on Succession of States in respect of State Property is not in force. In the twenty-five years since it was drafted, it has been ratified by only seven States. Moreover, the Convention was met with widespread opposition, and cannot be considered to be accepted by the international community as a whole. ${ }^{141}$ Even if the Convention was applicable, by its terms the Convention applies only in respect of the succession of States which has occurred after its entry into force. ${ }^{142}$ Finally, it would apply unless otherwise agreed by the parties. Spain claimed that any cession was governed by the Capitulation of Ayacucho. ${ }^{143}$

The Magistrate deemed Peru's requests as "inconsistent": "on one hand, Peru agreed that Spain was immune from Odyssey's salvage claims [...]; but on the other, it maintained that Spain was not immune from Peru's claim against the res". ${ }^{144}$ Instead, the Magistrate deemed that the jurisdictional nexus over the shipwreck was too tenuous to settle the dispute between two sovereigns over the remnants of a sunken warship. ${ }^{145} \mathrm{He}$ held that "Peru and Spain's dispute is intertwined with centuries of mutual history. Addressing their differences in this forum [...] would undermine the traditional notions of international comity [...]" and constitute an "unreasonable exercise of jurisdiction". ${ }^{146}$ In sum, the Magistrate concluded that "Spain and Peru's dispute over the specie is best resolved through direct negotiations between the two and not in this forum". ${ }^{147}$ The District Judge agreed with the Magistrate that the

${ }^{135}$ Ibid., p. 5.
${ }^{136}$ Ibid., p. 8.
${ }^{137}$ Ibid., p. 8.
${ }^{138}$ Ibid., p. 10 . In this regard, Spain expressly declared that "it chooses the International Tribunal for the Law of the Sea and the International Court of Justice as means for the settlement of disputes concerning the interpretation or application of the UNCLOS".

${ }^{139}$ Ibid., p. 10.

${ }^{140}$ Ibid., p. 11.

${ }^{141}$ Ibid., p. 11-12.

142 Ibid., p. 14.

${ }^{143}$ Ibid., p. 15.

144 Odyssey Marine Exploration, Inc. v. The Unidentified Shipwrecked Vessel, Report and Recommendation, 3 June 2009, Case No. 8:07-cv-614-T-23MAP, p. 29.

${ }^{145}$ Ibid., p. 31.

${ }^{146}$ Ibid., p. 32.

${ }^{147}$ Ibid., p. 33. 
principles articulated by [Peru] "may govern in another forum on another day in resolving Peru's challenge to Spain's retention of the disputed items". ${ }^{148}$

\section{CONCLUSIONS}

Shipwrecks are an invaluable source of knowledge and hold a profound historic and cultural value. ${ }^{149}$ From a historical perspective, the discovered goods may constitute a "difficult heritage" because they recall dramatic events of the past and stories of aggression and violence. Still, they offer us the possibility of remembering the dead and unveiling often neglected episodes of the past. From a cultural perspective, underwater cultural heritage represents an "integral part of the cultural heritage of humanity and a particularly important element in the history of peoples and their relations with each other concerning their common heritage". ${ }^{150}$ As a Hamilton once put it, "[maritime disputes] so generally depend on the laws of nations, and so commonly affect the rights of foreigners, they fall within the considerations which are relative to the public peace". ${ }^{151}$

The Black Swan case is a dispute which combines: "a compelling episode in naval history", the law of the sea, "the intriguing prospect of recovering great wealth lost in connection with an international conflict, the objective of respectful [...] preservation of warships [...] lost at sea, and the troubling question of the plight of both persons and natural resources subject to colonial exploitation". ${ }^{152}$ Several legal and political issues are raised by the case. First, it seems to reaffirm that "at least in the context of historic salvage, general maritime law only operates within the parameters of public international law and relies on national courts to apply it in an internationally sensitive manner". ${ }^{153}$ Second, it restates a distinction between private property and public property which is found in maritime powers' policy statements, national legislation, ${ }^{154}$ and even international law instruments. One may question, however, whether such a distinction makes sense with regard to underwater cultural heritage that is "an integral part of the cultural heritage of humanity and a particularly important element in the history of peoples, nations and their relations with each other concerning their common heritage". ${ }^{155}$ As one author puts it, "if the sunken vessel is private, then the treasure salvor has a greater chance of keeping everything recovered, perhaps worth millions. If the sunken vessel is public, then the sovereign retains ownership and the salvor is limited to reimbursement of his expenses". ${ }^{156}$ In the Odyssey case, no reimbursement was envisaged.

Can differential treatment for military sunken vessels be justified? Several considerations justify special treatment. Promotion of mutual respect among nations, comity of interest, national security, respect for maritime graves and, in particular, war cemeteries,

${ }^{148}$ Case No. 8:07-cv-614-T-23MAP, Order, 22 December 2009, cit. supra note 7, p. 4

149 See BOESTEN, Archaeological and/or Historic Valuable Shipwrecks in International Waters, Cambridge, 2002, p. 12.

${ }^{150}$ CPUCH, Preamble.

${ }^{151}$ THE FedERALIST No. 80 (Alexander Hamilton) (Jacob E. Cooke ed., 1961), at 536.

${ }^{152}$ Case No. 8:07-cv-614-T-23MAP, Order, 22 December 2009, cit. supra note 7, p. 2.

${ }^{153}$ NAFZIGER, "Historic Salvage Revisited", Ocean Development \& International Law, 2000, p. 81 ff., p. 85.

${ }^{154}$ At the statutory level, the recently enacted Sunken Military Craft Act (cit. supra note 41) provides that "[t]he law of finds shall not apply to [...] any foreign sunken military craft located in United States waters" and "[n]o salvage rights or awards shall be granted with respect to [...] any foreign sunken military craft located in the United States waters without the express permission of the relevant foreign state". For a commentary, see BEDERMAN, "Congress Enacts Increased Protections for Sunken Military Craft", AJIL, 2006, pp. 649-663.

${ }^{155}$ CPUCH, Preamble.

156 YEATES, cit. supra note 76, p. 371. 
are just some of the reasons that would demand such special treatment. Whether there exists a customary norm in this regard it is still debated. However, opinio juris and State practice are gradually coalescing in this sense. Will the special status of military sunken vessels discourage salvors? Will it encourage further opacity and unlawful excavation? At the time of this writing, Odyssey and Peru are appealing to the United States Court of Appeals for the Eleventh Circuit from the final order of dismissal and the final judgment. ${ }^{157}$ It is still too early to foresee the outcome of the case. Does the case have the potential for reaching the US Supreme Court? This seems doubtful as there seems to be a uniform trend towards an increased protection of military sunken vessels at both the national and international levels. Therefore, the rule of law seems clearly stated, and the decision, if confirmed, does not seem to have departed "from the accepted and usual course of judicial proceedings". 158 Furthermore, the US Supreme Court has rarely granted certiorari, i.e. agreed to hear maritime law cases. ${ }^{159}$

Whatever the result of the case, the Black swan case - whereby private actors release minimal information about the project, until after the excavation has been completed - raises important ethical issues. The comparative advantage of the salvor is two-fold. "First, because the sovereign's interest is subject to the vessel's origin and identity, the salvor can exercise control over the vessel for the time being, while the sovereign, as a potential owner, can only speculate on the validity of its claims [...]". ${ }^{160}$ Second, "the nature of salvage law in permitting salvage awards while ownership remains inconclusive encourages the salvor to focus its efforts on salvage rather than on efforts to identify the vessel [...]". ${ }^{161}$

An eminent author once affirmed that "admiralty courts [...] provide an alternative to lawlessness on the frontier of underwater cultural heritage and thereby fill a void", ${ }^{162}$ and that "admiralty courts are justice-administering institutions in a cosmopolitan sense and not simply bodies for implementing local policies". ${ }^{163}$ Issues of international comity may make these courts impartial and high-profiled. However, issues of extra-territoriality arise. Furthermore, salvage law has not yet developed procedural and substantive guarantees to adequately protect underwater cultural heritage. Dealing with claims filed by individuals, admiralty courts have applied salvage law to an overwhelming number of cases concerning underwater cultural heritage. However, these courts have rarely questioned whether salvage law is appropriate at all for historic shipwrecks. Only in recent cases, has attention been paid to deep water archaeological methodology. ${ }^{164}$ In this context, while some authors criticize admiralty law as allowing "freedom of fishing" or "first-come first-served approach", ${ }^{165}$

${ }^{157}$ Odyssey Marine Exploration Inc. v. The Unidentified Shipwrecked Vessel, Case No. 8:07-cv-00614-T23MAP, Notice of Appeal [by Odyssey Marine], 15 January 2010; Odyssey Marine Exploration Inc. v. The Unidentified Shipwrecked Vessel, Case No. 8:07-cv-00614-SDM-MAP, Notice of Appeal [by Odyssey Marine], 19 January 2010.

${ }^{158}$ Supreme Court Rules, Rule 3.

${ }^{159}$ The US Supreme Court gained the right of judicial discretion in determining which cases it hears in the Judiciary Act of 1925. Review on a writ of certiorari is not a matter of right, but of judicial discretion.

${ }^{160}$ TSAI, "Curse of the Black Swan: How the Law of Salvage Perpetuates Indeterminate Ownership of Shipwrecks”, International Lawyer, 2008, p. 211 ff., p. 218.

${ }^{161}$ Ibid.

${ }^{162}$ NAFZIGER, cit. supra note 36, p. 256.

163 Ibid., p. 260.

${ }^{164}$ For instance, in Bemis v. RMS Lusitania, the US Federal Appellate Court denied the claimant's salvor status over the Lusitania wreck, because only few artifacts had been recovered. Also, the Court restrained the salvor from taking artifacts from the wreck because of its scientific, historic and archaeological significance. Bemis v. RMS Lusitania, US Federal Appellate Court 884 F Supp 1042.

${ }^{165}$ SCOVAZZI, "The 2001 UNESCO Convention on the Protection of the Underwater Cultural Heritage", in HofFMAN (ed.), cit. supra note 112, p. 285 ff., p. 288; ScOVAZZI, "The Entry into Force of the 2011 UNESCO Convention on the Protection of the Underwater Cultural Heritage", Aegean Review of the Law of the Sea, 2010, p. 19 ff., p. 25 . 
others underline the recent developments in admiralty law as a promising pattern. ${ }^{166}$ It is worth considering that other fora are available albeit at the inter-State level. ${ }^{167}$ In this context, military sunken vessels involve issues of ownership and State immunity. With regard to the ownership of underwater cultural heritage, the CPUCH does not address this issue. Therefore, the regime established by the UNCLOS, which is deemed to reflect customary international law, still generally applies. UNCLOS, however, provides only general principles for establishing the ownership of the vessel and the objective of preserving archaeological and historical objects for the benefit of mankind. It is unclear whether UNCLOS provisions concerning military vessels can be applied to sunken warships. In this sense, the CPUCH contains special provisions for the recovery of such warships. Maritime powers insist on a rule that would require the consent of the flag State even in territorial waters. It remains to be seen whether this firm and uniform approach may determine the crystallization of a norm of customary law.

${ }^{166}$ BRYANT, "The Archaeological Duty of Care: The Legal, the Professional and Cultural Struggle Over Salvaging Historic Shipwrecks", Albany Law Review, 2001, p. 97 ff.; BEDERMAN, "Building New Regimes and Institutions for the Sea: Historic Salvage and the Law of the Sea", University of Miami Inter-American Law Review, 1998, p. 99 ff.

${ }^{167}$ Inter-state fora include the International Court of Justice and, if the parties have ratified UNCLOS, the International Tribunal for the Law of the Sea. Alternative dispute resolution mechanisms, such as arbitration and mediation are also available. Investor-State arbitration may become another possible forum for disputes between salvors and coastal States. See VADI, "Investing in Culture: Underwater Cultural Heritage and International Investment Law”, Vanderbilt Journal of Transnational Law, 2009, p. $853 \mathrm{ff}$. 